\title{
Design and technical characteristics of shark gillnet operating in Mumbai coast
}

\author{
Shabir A. Dar ${ }^{1^{*}}$, Saly N. Thomas ${ }^{2}$ and S. K. Chakraborty ${ }^{3}$ \\ ${ }^{1}$ Faculty of Fisheries, Sher-e-Kashmir University of Agricultural Sciences and Technology of Kashmir - 190006 \\ ( $\mathrm{J} \& \mathrm{~K})$, INDIA \\ ${ }^{2}$ Central Institute of Fisheries Technology, Willington Island, Cochin - 682029 (Kerala), INDIA \\ ${ }^{3}$ Central Institute of Fisheries Education, Versova, Mumbai - 400061 (Maharastra), INDIA \\ *Corresponding author. E-mail: shabirdar777@rediffmail.com
}

Received: May 31, 2016; Revised received: February 1, 2017; Accepted: April 25, 2017

\begin{abstract}
This paper deals with design and general features of shark gillnets operated along Mumbai coast. A PA monofilament of 0.60 to $1.0 \mathrm{~mm}$ diameter and selvedge meshes of PE of 1 to $2 \mathrm{~mm}$ diameter were used for shark set gillnets along Mumbai coast. Mesh size of the main webbing ranged from 120 to $200 \mathrm{~mm}$ with average of 144.4 $\pm 10.83 \mathrm{~mm}$ and rigged with a hanging coefficient of 0.41 to 0.51 with average of 0.42 were commonly used. A hung length ranging from 40 to $105 \mathrm{~m}$ with mean of $59 \pm 10.37$ with total hung depth varying from 6.42 to $10.58 \mathrm{~m}$ with average of $8.15 \pm 0.49 \mathrm{~m}$. Shark gillnet had a total length of 260 to $456 \mathrm{~m}$ with mean of $350.71 \pm 28.53 \mathrm{~m}$. The nets were operated mostly at a depth up to $18 \mathrm{~m}$ very near to the shore and were of set type of gillnet. Polyamide (PA) monofilament netting of 0.16 to $0.32 \mathrm{~mm}$ diameter and of mesh size $26-200 \mathrm{~mm}$ were generally used for construction of gillnets throughout the Mumbai coast. Polyamide (PA) monofilament has completely replaced PA multifilament in all the nets except those targeted i.e. white sardine and seerfish.
\end{abstract}

Keywords: Design, Mumbai Coast, Polyamide, Shark gillnet

\section{INTRODUCTION}

Gillnet is one of the oldest type of fishing gear and is widely used to harvest diverse marine species (Sainsbury, 1996). Gillnetting, the name itself is a self explanatory which means fishes are caught by gilling. Fish caught in gillnet are usually gilled, but can be wedged, snagged or entangled (Hovgard and Lassen, 2000). Gillnets vary in material, mesh size and dimension depending on the target species. Specific gillnets targeting particular resources are named after targeted resource. Important types of gillnets in operation along Mumbai coast are sardine gillnets, white sardine gillnets, mackerel gillnets, seerfish gillnets, pomfret gillnets, shark gillnets, solefish gillnets and shrimp gillnets. Gillnet fishing is one of the popular fishing methods along the west coast of India. Gillnetting has become popular among fishers being less capital intensive, selectively operated depending on availability and demand and can be operated at areas where bottom is not suitable for trawling. Among the gear wise contribution to all India marine landings, the gillnets contributed $21 \%$ with $6 \%$ mechanised and $15 \%$ motorised sector during 2007 (Ramani et al., 2010). So the information on selectivity properties of gillnets helps in regulation of mesh size and optimization of gillnet design in order to facilitate selective harvesting of targeted species or size groups, supporting responsi- ble fisheries (Thomas, 2009).

Though gillnets of Maharashtra play a prominent role in the marine fish landings of the state, a comprehensive study on this fishery with special focus on design and technical details of shark gillnets have made which has not been done earlier. Since 1980's many need based changes have taken place mainly with respect to material substitution, changes in method of operation, introduction of resource specific gear, use of coloured webbing, motorisation and other changes consequent to this.

\section{MATERIALS AND METHODS}

Fishing season in Maharashtra starts on the day of NaraliPournima or on $15^{\text {th }}$ of August, whichever is earlier whereas it is closed before onset of monsoon or generally on $10^{\text {th }}$ June. Fishing activities remain suspended in most of the landing centres in this region during the monsoon months as the fishermen find it difficult to navigate their vessels due to rough weather. In addition to this, as per Maharashtra Marine Fishing Regulation Act, 1981, there is a ban on fishing in monsoon season from 10 June to 15 August or up to NaraliPournima, whichever is earlier. So, data were collected from $1^{\text {st }}$ December 2010 to $30^{\text {th }}$ November 2011 except during the fishing ban period.

For collecting the design and technical details of gear and craft scheduled I was used. It covers aspects such 
as technical specifications, design aspects, rigging and mode of operation of shark marine gillnets used by the fisherman were physically collected according to Thomas and Hridayanathan (2006). Detailed information was also collected from the operators of the units and commission agents /middle man to verify the data. The data related to the technical specification, design details and operation shark gillnets, the craft used and mode of operation were recorded. The design of the gear was documented following Nedelec (1975). Metric system was used for dimensions. Meter (m) was used for larger dimensions like length of foot rope, head rope and float line and millimeter $(\mathrm{mm})$ was used for smaller dimensions such as mesh size, diameter of ropes and float dimensions. The unit for mass and weight was the kilogram $(\mathrm{kg})$ and gram $(\mathrm{g})$. Materials were indicated by abbreviations which were based on terminology used in common international usage (Nedelec, 1975). The size of netting yarns was presented according to the tex system (Klust, 1973).

The mesh size was represented as stretched mesh i.e. the distance between the centres of the two opposite knots in the same mesh when fully stretched in the 'normal' $(\mathrm{N})$ direction. The dimensions of the net panels in length and width or depth were defined by the number of meshes in straight row along the edges where applicable. The hanging coefficient denoted as E. Ropes were drawn by thick lines and specified by their length in meters, the material and their diameter in $\mathrm{mm}$.

\section{RESULTS AND DISCUSSION}

During the present study, operation of shark gillnet was observed at all the three selected landing centres viz. Cuff Parade, Versova and Mahim. The nets were of set gillnet type and operated very near to the shore. The specifications and design of a typical shark gillnet are given in Table 1 and Fig. 1. PA monofilament of 0.60 to $1.0 \mathrm{~mm}$ diameter and selvedge meshes of PE of 1 to $2 \mathrm{~mm}$ diameter were used for shark set gillnets. Mesh size of the main webbing ranged from 120 to $200 \mathrm{~mm}$ with average of $144.4 \pm 10.83 \mathrm{~mm}$ and rigged with a hanging coefficient of 0.41 to 0.51 with average of 0.42 were commonly used. Shark gillnets have hung length ranging from 40 to $105 \mathrm{~m}$ with mean of 59 \pm 10.37 with total hung depth varying from 6.42 to $10.58 \mathrm{~m}$ with average of $8.15 \pm 0.49 \mathrm{~m}$. The shark gillnet had a total length of 260 to $456 \mathrm{~m}$ with mean of $350.71 \pm 28.53 \mathrm{~m}$. The net was operated mostly at a depth up to $18 \mathrm{~m}$, near to the shore line.

Stones/cement was used as sinkers and was attached directly to the foot rope at regular intervals. Two heavy stones $(10 \mathrm{~kg}$ each) were attached at both the ends of the fleet which acted as anchors. Head rope and foot rope were of 5 to $8 \mathrm{~mm}$ diameter. Mounting ropes were totally absent. Generally, lead line and float line ratio in shark gillnet was one. Expanded PVC floats of 10 to 20 numbers per unit were used on head rope and 10 to 18 numbers of stones of 250 to $400 \mathrm{~g}$ weight per unit as sinkers on foot rope. Four to eight units were joined end to end by making knots at head and foot

Table 1. Technical specifications of shark bottom set gillnet.

\begin{tabular}{lc}
\hline Station & Mahim \\
\hline Local name & Mushichijali \\
Main webbing mesh size $(\mathrm{mm})$ & $120-200$ \\
Twine type & PA mono \\
Twine specification /diameter $(\mathrm{mm})$ & $0.60-1.00$ \\
No. of meshes in depth & 50 \\
Hanging coefficient $(\mathrm{E})$ & $0.41-0.51$ \\
No. of meshes per unit & $630-1824$ \\
Hung length (m) & $260-460$ \\
Hung depth (m) & $5.42-7.75$ \\
Colour of webbing & Colourless/ Light green \\
Selvedge mesh in depth & \\
Selvedge hung depth $(\mathrm{m})$ & \\
Head rope material & $0.10-0.17$ \\
Head rope diameter $(\mathrm{mm})$ & PP \\
Float material & $5-8$ \\
Float dimensions (mm) & PVC \\
No. of floats per unit & $80 \times 15 / 140 \times 15$ \\
Foot rope material & $12-20$ \\
Foot rope diameter (mm) & PP \\
Sinker material & 8 \\
Sinker weight (g) & Concrete \\
No. of sinker per unit & $250-300$ \\
Total fleet length (m) & $10-18$ \\
Depth of operation (m) & $260-456$ \\
Fishing craft & Upto 18 \\
Horse power of the engine (hp) & Nil-20 \\
\hline & \\
\hline
\end{tabular}



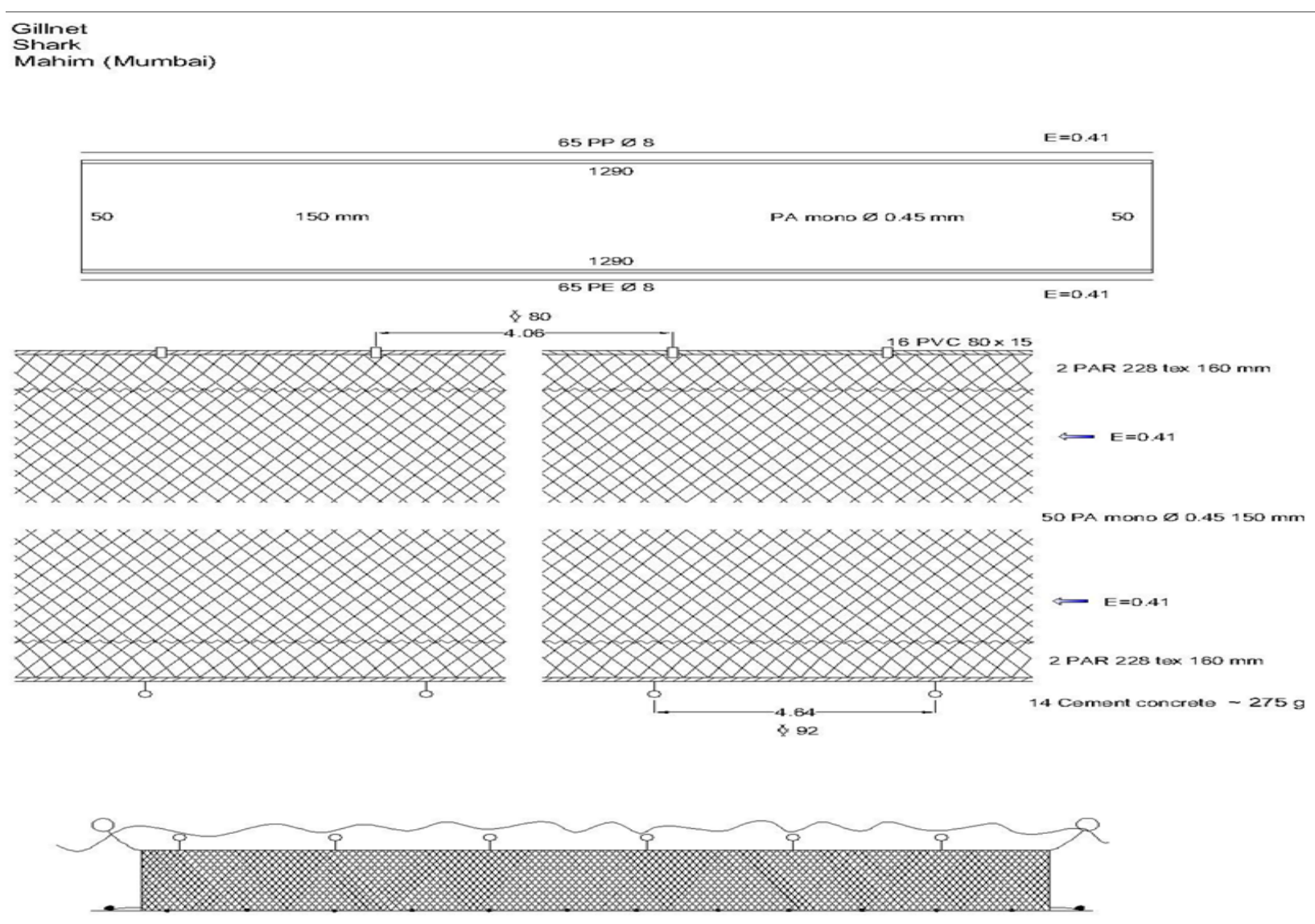

Fig. 1. Design of shark gillnet operating at Mumbai coast.

ropes as well as seaming at regular intervals throughout the depth of net to form a netting fleet.

In Mumbai the shark gillnets were operated as set gillnets very near to the shore. Vijayan et al. (1993) reported that shark gillnets were operated as column set gillnets either from motorized or non-motorized fishing crafts by adjusting the fishing height and depth of operation. Pravin et al. (1998) reported that the shark gillnets of Gujarat were used as surface drift, column drift and bottom drift as well as set gillnets. In Kerala, Thomas and Hridayanathan (2006) observed that shark gillnets were operated as both drift nets and set nets. Set gillnets of PA monofilament of 0.50 to $1.00 \mathrm{~mm}$ diameter were operated to target sharks in Mumbai. HDPE gillnets with larger meshes for deep water fishing were very successful all along the Saurashtra and South Gujarat coast (Pillai, 1989; Pravin et al., 1998). These gillnets were fabricated with HDPE twine of 1 to $2.5 \mathrm{~mm}$ diameter. In earlier days, nylon twines of $210 \mathrm{~d} \times 9 \times 3$ and $210 \mathrm{~d} \times 24 \times 3$ were used for shark gillnets . Due to the high cost of nylon, PE twines were mostly used for deep water shark gillnets in Gujarat (Pillai, 1989). Shark gillnets were made up of hemp material in 1958 and nylon multifilament with specification of $210 \mathrm{~d} \times 24 \times 3$ were in operation during 1991 in Kerala (Vijayan et al., 1993). PA multifilament material for shark gillnets reported by different workers was not observed during present study. In
Mumbai coast for catching sharks, gillnets PA monofilament was commonly used. Targeted sharks in Mumbai are smaller in size as evidenced from the relatively smaller mesh sizes used. Therefore, PA monofilament gillnet is used in this coast unlike in Gujarat where bigger sharks are targeted. Shark gillnets with mesh size ranging between 120 to $200 \mathrm{~mm}$ were in operation in Mumbai. HDPE gillnets with mesh size in the range of 170 to $250 \mathrm{~mm}$ were used along the Gujarat coast for shark fishing (Pillai, 1989). Vijayan et al. (1993) reported the shark gillnets of mesh size 250 to 350 in 1958 and 230 to 250 in 1991 from Kerala while larger mesh sizes of upto $400 \mathrm{~mm}$ was used for catching sharks in Gujarat (Thomas et al., 2005). During present investigation it was observed that, shark gillnets were used at bottom and operated near the coast having hung depth ranging from 5.82 to $10.58 \mathrm{~m}$. Vijayan et al. (1993) recorded a hung depth of $3.7 \mathrm{~m}$ in 1958 and $7.0 \mathrm{~m}$ in 1991 for sharks gillnets from Kerala. Thomas and Hridayanathan (2006) recorded the hung depth of $9.73 \mathrm{~m}$ for shark gillnets of Kerala. In Mumbai, the shark gillnets had a total length of 260 to $550 \mathrm{~m}$ with depth of operation up to $18 \mathrm{~m}$ and were operated from mechanized, motorised and nonmechanized fishing craft. In 1991, shark gillnets with total length of $350 \mathrm{~m}$ and depth of operation of 20 to $25 \mathrm{~m}$ were in operation from motorized and non motorized fishing craft in Kerala (Vijayanet al., 1993). 
Pillai (1989) observed the fishing operation of shark gillnets in Gujarat and reported that vessels operated gillnet is bottom set and surface drift mostly during the night at a depth range of 75 to 150 metres. In Kerala, Thomas and Hridayanathan (2006) reported shark gillnets with the total net length of 800 to $1280 \mathrm{~m}$ with the depth of operation from 19 to $300 \mathrm{~m}$. The fleet length of shark gillnets operated in Kerala (Thomas and Hridayanathan, 2006) was more than triple observed during the present study. The depth of operation for shark fishing was very less than the depth of operation observed from other parts of Indian coast line (Vijayan et al., 1993; Pillai, 1989 and Thomas and Hridayanathan, 2006).

\section{Conclusion}

Sharks gillnets were prevalent in all the selected landing centres operated by mechanised and motorised and traditional gillnetters. The fishing gear material of $\mathrm{P}$. A. monofilament of 0.60 to $1.0 \mathrm{~mm}$ diameter and selvedge meshes of P. E. of 1 to $2 \mathrm{~mm}$ diameter were used for shark gill nets with mesh size of the main webbing ranged from 120 to $200 \mathrm{~mm}$ with average with average of $144.4 \pm 10.83 \mathrm{~mm}$ and rigged with a hanging coefficient of 0.41 to 0.51 . There are no regulations regarding elasmobranches fisheries exist under the department of Fisheries of Maharashtra. So for the proper management shark fisheries along Mumbai coast which are critically endangered under the IUCN Red List (2000), clear guide lines are to be formulated regarding design and operational methods.

\section{REFERENCES}

Hovgard, H. and Lassen, H. (2000). Manual on estimation of selectivity for the gillent and longlinersgeasr in abundance survesy. FAO Fisheries technical paper. No.
397. Rome

Klust, G. (1973). Netting materials for fishing gear Fishing News (Books) Ltd., England, 173 p.

Nedelec, C. (1975). FAO Catalogue of small scale fishing gear, Fishing News (Books) Ltd., Farnham, Surrey, England, $191 \mathrm{pp}$.

Pillai, N. S. (1989). An overview of shark gillnetting in $\mathrm{Gu}-$ jarat. Fishing Chimes, 9: 37 - 42

Pravin, P., Ramesan, M. P. and Mathai, P. G. (1998). Gillnet fishing in Gujarat, In: Advances and Priorities in Fisheries Technology, Balachandran, K.K., Iyer, T.S.G., Madhavan, P., Joseph, J., Perigreen, P. A., Raghunath, M.R and Varghese, M.D. (Eds.), Society of Fisheries Technology (India), Cochin, Pp.170-176

Ramani K., Ammini P. L., Srinivasan, J., NajeemudeenHaja S., Beena M. R., George K. P., Seynudee M. B., Sunnaraman G., Anandan K., Khambadkar Lata L., Augustine Sindu K., Pugazhendi D., Rudhramurthy N., Subramani S., Seetharaman, S., Kather Batch H. and Sankaralingam S. (2010). An overview of marine fisheries in India during 2007. Mar. Fish, Infor. Ser. T \& E Ser., No. 203.

Sainsbury, J. C. (1996). Comermercila Fishing methods. Oxford: Osney Meas. 3rd Edition.

Thomas, S. N. and Hridayanathan, C. (2006). Design and general characteristics of marine gillnet of Kerala. Fish. Technol., 43: 17-36

Thomas, S. N. (2009). Selectivity of gillnets, In: Meenakumari, B., Boopendranath, M. R., Pravin, P., Thomas S. N. and Edwin, L., (Eds.). Handbook of Fishing Technology, Central Institute of Fisheries Technology, Cochin, 146-151

Thomas, S. N., Meenakumari B., Pravin, P. and George Mathal, P. (2005). Gillnets in Marine Fisheries of India. Monograph, Agriculture Technology Centre, Central Institute of Fisheries Technology, Cochin, Pp. 45

Vijayan, V., Varghese, M. D., Edwin L., Thomas, S. N. and George, V. C. (1993). Coastal Gillnets of Kerala Changes in their decades In: Low Energy Fishing. Fish. Technol. (Special Issue on Low energy Fishing) Society of Fisheries Technologists, India, 170-176 